\title{
Secretion of blood group substances in duodenal, gastric and stomal ulcer, gastric carcinoma, and diabetes mellitus
}

\author{
R. DOLL, H. DRANE, AND A. C. NEWELL \\ From the Central Middlesex Hospital and the Statistical Research Unit, \\ Medical Research Council, London
}

SYNOPSIS The ABO blood group and ABH secretor status have been determined for 368 patients with a duodenal ulcer, 202 patients with a gastric ulcer, 83 patients with a stomal ulcer, 105 patients with gastric cancer, 102 patients with diabetes mellitus, and a control group of 610 subjects consisting of healthy persons and of patients with other conditions attending the same hospital.

The results have been analysed in conjunction with those reported in two other large series. For duodenal ulcer the results show that the relative incidence among non-secretors compared with secretors is 1.80 to 1 , with $95 \%$ confidence limits of 1.55 to 1 and 2.03 to 1 . For gastric ulcer the relative incidence is 1.42 to 1 , with $95 \%$ confidence limits of 1.16 to 1 and 1.74 to 1 . Comparison of the results for the two types of peptic ulcer shows that they are significantly different from one another.

For both types of ulcer, the estimated risk among non-secretors was similar for blood group $\mathrm{O}$ and for the other blood groups and the results suggest that the specific risks associated with blood group $\mathrm{O}$ and with non-secretion multiply one another. It is concluded that the mechanisms by which blood group $\mathrm{O}$ and non-secretion affect the risk of developing a gastric or duodenal ulcer are related to one another; but that they do not depend on the presence of the blood group substances in the secretions.

The proportion of non-secretors among patients with a stomal ulcer $(49 \%)$ was higher than among patients with a duodenal ulcer $(37 \%)$ and the order of the relationship between non-secretion and the three types of peptic ulcer (stomal, duodenal, and gastric) was the same as that for blood group $\mathrm{O}$.

Other data suggest that there may be a slight increase in the risk of gastric cancer among nonsecretors, but that the occurrence of diabetes mellitus is independent of $\mathrm{ABH}$ secretion.

Interest in the association between gastrointestinal disease and the $\mathrm{ABO}$ blood group substances was enhanced by the discovery that there was also an association between duodenal ulcer and failure to secrete the substances in the mucous secretions (Clarke, Edwards, Haddock, Howel-Evans, McConnell, and Sheppard, 1956; Clarke, Evans, McConnell, and Sheppard, 1959). Not everyone is capable of secreting these substances; but, among those who are, the substances form a major part of the soluble mucus. It seemed reasonable, therefore, to suppose that the association between particular diseases and the different blood groups might be due to a difference in the quality of the protective power of the different types of mucus. One finding weighed against this explanation. According to Clarke and his colleagues the association between duodenal ulcer and group $\mathrm{O}$ was no stronger among secretors than among non-secretors, whereas if the effect of the group substances was exerted locally in the lumen of the gut, it would have been expected that the association would have been limited to secretors.

Our inquiry was undertaken (1) to see if the observations on duodenal ulcer could be confirmed, and (2) to investigate the incidence of non-secretors in some other diseases which were known to be associated with one or other of the ABO blood groups. 
METHOD

Secretion of the ABO blood group substances was tested by seeing whether the subject's saliva would prevent the agglutination of group $\mathrm{O}$ red cells by an extract of the seeds of Ulex europaeus. This extract reacts with the $\mathbf{H}$ antigen common to all the ABO blood groups and has been found to react with the saliva of all secretors, irrespective of the blood group to which they belong (Boyd and Shapleigh, 1954; Clarke et al., 1956). The adequacy of the method was confirmed in a few subjects belonging to groups $\mathrm{A}, \mathrm{B}$, and $\mathrm{AB}$ by the use of anti-A or anti-B sera and, in selected subjects belonging to groups $\mathbf{O}$ and $\mathrm{A}$, by testing for the presence of Lewis antigens in the blood. Apart from a few subjects who were negative for both the Lewis antigens, all nonsecretors were positive for Lewis a $(\operatorname{Le} \mathrm{a}+)$ and all secretors positive for Lewis $b(\operatorname{Le} b+)$.

The patients attended the Central Middlesex Hospital. No attempt was made to obtain a consecutive series but care was taken to ensure that the choice was not influenced by knowledge of the ABO blood group. Patients were selected because they were known to be suffering from a peptic ulcer, gastric cancer, diabetes mellitus, or ulcerative colitis. Other persons examined consisted of (1) patients admitted to the general medical and surgical wards of the hospital who were not suffering from any of the above conditions, and (2) healthy subjects, i.e., blood donors, members of the hospital staff, medical colleagues, personal friends, and the spouses of patients.

Patients were excluded if they suffered from a condition suggestive of a peptic ulcer, without the presence of an ulcer having been established, or if they were known to have had both gastric and duodenal ulcers. Africans and West Indians were excluded irrespective of the condition from which they suffered.

Data on patients with ulcerative colitis are omitted from the present report, as the number of patients studied (44) is too small for separate analysis.

\section{RESULTS}

Data obtained from 385 healthy subjects and 225 patients suffering from conditions other than those under special study are shown in Table I. The results are closely similar in the two groups and they have, therefore, been combined to provide a single control series. Table II shows the distribution of the ABO blood groups in the combined series as compared with that reported by Discombe and Meyer (1952) for 10,000 women attending ante-natal clinics in the area of the Central Middlesex Hospital. The two sets of results are almost identical. Table III shows the proportion of non-secretors in the control series compared with that reported by Glynn, Glynn, and

\section{TABLE I}

NUMBER OF SECRETORS AND NON-SECRETORS AMONG CONTROL SUBJECTS BY SEX AND BLOOD GROUP

\begin{tabular}{|c|c|c|c|c|c|c|c|c|c|c|c|}
\hline \multirow[t]{3}{*}{ Category of Subjects } & \multirow[t]{3}{*}{ Sex } & \multicolumn{8}{|c|}{ Number of Persons in Blood Group } & \multirow{3}{*}{$\begin{array}{l}\text { Total } \\
\text { Number } \\
\text { of } \\
\text { Subjects }\end{array}$} & \multirow{3}{*}{$\begin{array}{l}\text { Percentage } \\
\text { Non- } \\
\text { secretors }\end{array}$} \\
\hline & & \multicolumn{2}{|l|}{$O$} & \multicolumn{2}{|l|}{$A$} & \multicolumn{2}{|l|}{$\boldsymbol{B}$} & \multicolumn{2}{|l|}{$A B$} & & \\
\hline & & Secretors & $\begin{array}{l}\text { Non- } \\
\text { secretors }\end{array}$ & Secretors & $\begin{array}{l}\text { Non- } \\
\text { secretors }\end{array}$ & Secretors & $\begin{array}{l}\text { Nol:- } \\
\text { secretors }\end{array}$ & Secretors & $\begin{array}{l}\text { Ncri- } \\
\text { secretors }\end{array}$ & & \\
\hline Healthy subjects & $\begin{array}{l}\mathbf{M} \\
\mathbf{F} \\
\mathbf{M}+\mathbf{F}\end{array}$ & $\begin{array}{r}49 \\
81 \\
130\end{array}$ & $\begin{array}{l}11 \\
28 \\
39\end{array}$ & $\begin{array}{r}55 \\
81 \\
136\end{array}$ & $\begin{array}{l}15 \\
16 \\
31\end{array}$ & $\begin{array}{l}16 \\
14 \\
30\end{array}$ & $\begin{array}{r}6 \\
5 \\
11\end{array}$ & $\begin{array}{l}1 \\
6 \\
7\end{array}$ & $\begin{array}{l}0 \\
1 \\
1\end{array}$ & $\begin{array}{l}153 \\
232 \\
385\end{array}$ & $\begin{array}{l}21 \cdot 1 \\
21 \cdot 6 \\
21 \cdot 3\end{array}$ \\
\hline $\begin{array}{l}\text { Patients suffering from con- } \\
\text { ditions other than those } \\
\text { under special study }\end{array}$ & $\begin{array}{l}\mathbf{M} \\
\mathbf{F} \\
\mathbf{M}+\mathbf{F}\end{array}$ & $\begin{array}{l}39 \\
46 \\
85\end{array}$ & $\begin{array}{r}8 \\
10 \\
18\end{array}$ & $\begin{array}{l}29 \\
44 \\
73\end{array}$ & $\begin{array}{r}4 \\
18 \\
22\end{array}$ & $\begin{array}{r}7 \\
6 \\
13\end{array}$ & $\begin{array}{l}2 \\
4 \\
6\end{array}$ & $\begin{array}{l}1 \\
6 \\
7\end{array}$ & $\begin{array}{l}1 \\
0 \\
1\end{array}$ & $\begin{array}{r}91 \\
134 \\
225\end{array}$ & $\begin{array}{l}16 \cdot 5 \\
23 \cdot 9 \\
20 \cdot 9\end{array}$ \\
\hline All categories & $\begin{array}{l}\mathbf{M} \\
\mathbf{F} \\
\mathbf{M}+\mathbf{F}\end{array}$ & $\begin{array}{r}88 \\
127 \\
215\end{array}$ & $\begin{array}{l}19 \\
38 \\
57\end{array}$ & $\begin{array}{r}84 \\
125 \\
209\end{array}$ & $\begin{array}{l}19 \\
34 \\
53\end{array}$ & $\begin{array}{l}23 \\
20 \\
43\end{array}$ & $\begin{array}{r}8 \\
9 \\
17\end{array}$ & $\begin{array}{r}2 \\
12 \\
14\end{array}$ & $\begin{array}{l}1 \\
1 \\
2\end{array}$ & $\begin{array}{l}244 \\
366 \\
610\end{array}$ & $\begin{array}{l}19 \cdot 3 \\
22 \cdot 4 \\
21 \cdot 1\end{array}$ \\
\hline
\end{tabular}

Difference between proportions of non-secretors in:

$\begin{array}{ll}\text { Men and women } & x^{2}=0.857, \mathrm{n}=1,0.30<P<0.50 \\ \text { Healthy subjects and hospital patients } x^{2}=0.014, \mathrm{n}=1,0.90<\mathrm{P}<0.95\end{array}$

$\begin{array}{ll}\text { Healthy subjects and hospital patients } x^{2}=0.014, \mathrm{n}=1,0.90<\mathrm{P}<0.95 \\ \text { Groups } \mathrm{O}, \mathrm{A} \text {, and B plus AB } & \chi^{2}=0.816, \mathrm{n}=2,0.50<\mathrm{P}<0.70\end{array}$

TABLE II

DISTRIBUTION OF ABO BLOOD GROUPS IN CONTROL SERIES AND COMPARED WITH THAT IN A PREVIOUS SERIES FROM SAME AREA

\begin{tabular}{|c|c|c|c|c|c|}
\hline \multirow[t]{2}{*}{ Series } & \multicolumn{4}{|c|}{ Percentages of Persons in Blood Group } & \multirow{2}{*}{$\begin{array}{l}\text { Total Number of } \\
\text { Subjects }\end{array}$} \\
\hline & $O$ & $A$ & $\boldsymbol{B}$ & $A B$ & \\
\hline $\begin{array}{l}\text { Present control series } \\
\text { Discombe and Meyer (1952) }\end{array}$ & $\begin{array}{l}44 \cdot 6 \\
45 \cdot 8\end{array}$ & $\begin{array}{l}43 \cdot 0 \\
42 \cdot 2\end{array}$ & $\begin{array}{l}9 \cdot 8 \\
8 \cdot 9\end{array}$ & $\begin{array}{l}2 \cdot 6 \\
3 \cdot 1\end{array}$ & $\begin{array}{r}610(100.0 \%) \\
10,000(100.0 \%)\end{array}$ \\
\hline
\end{tabular}


TABLE III

NUMBER OF SECRETORS AND NON-SECRETORS AMONG CONTROL SUBJECTS BY SEX AND BLOOD GROUP IN COLLECTED SERIES

\begin{tabular}{|c|c|c|c|c|c|c|c|c|c|c|c|}
\hline \multirow[t]{3}{*}{ Series } & \multirow[t]{3}{*}{ Sex } & \multicolumn{8}{|c|}{ Number of Persons in Blood Group } & \multirow{3}{*}{$\begin{array}{l}\text { Total } \\
\text { Number } \\
\text { of } \\
\text { Subjects }\end{array}$} & \multirow{3}{*}{$\begin{array}{l}\text { Percentage } \\
\text { of } \\
\text { Non- } \\
\text { secretors }\end{array}$} \\
\hline & & \multicolumn{2}{|l|}{$O$} & \multicolumn{2}{|l|}{$A$} & \multicolumn{2}{|l|}{$\boldsymbol{B}$} & \multicolumn{2}{|l|}{$A B$} & & \\
\hline & & Secretors & $\begin{array}{l}\text { Non- } \\
\text { secretors }\end{array}$ & Secretors & $\begin{array}{l}\text { Non- } \\
\text { secretors }\end{array}$ & Secretors & $\begin{array}{l}\text { Non- } \\
\text { secretors }\end{array}$ & Secretors & $\begin{array}{l}\text { Non- } \\
\text { secretors }\end{array}$ & & \\
\hline Glynn et al. (1959) & $M \& F$ & - & - & - & - & - & - & - & - & 669 & $22 \cdot 9$ \\
\hline McConnell (1961a, 1961b) & $\begin{array}{l}\mathbf{M} \\
\mathbf{F}\end{array}$ & $\begin{array}{l}144 \\
172\end{array}$ & $\begin{array}{l}46 \\
48\end{array}$ & $\begin{array}{l}138 \\
116\end{array}$ & $\begin{array}{l}42 \\
42\end{array}$ & $\begin{array}{l}46 \\
21\end{array}$ & $\begin{array}{l}12 \\
12\end{array}$ & $\begin{array}{r}10 \\
7\end{array}$ & $\begin{array}{l}2 \\
2\end{array}$ & $\begin{array}{l}440 \\
421\end{array}$ & $\begin{array}{l}23 \cdot 2 \\
24 \cdot 9\end{array}$ \\
\hline Newman et al. (1961) & $\begin{array}{l}\mathbf{M} \\
\mathbf{F}\end{array}$ & $\begin{array}{l}250 \\
197\end{array}$ & $\begin{array}{l}69 \\
47\end{array}$ & $\begin{array}{l}233 \\
154\end{array}$ & $\begin{array}{l}75 \\
50\end{array}$ & $\begin{array}{l}66 \\
41\end{array}$ & $\begin{array}{l}19 \\
18\end{array}$ & $\begin{array}{l}20 \\
10\end{array}$ & $\begin{array}{l}7 \\
5\end{array}$ & $\begin{array}{l}739 \\
522\end{array}$ & $\begin{array}{l}23 \cdot 0 \\
23 \cdot 0\end{array}$ \\
\hline Present control series & $\begin{array}{l}\mathbf{M} \\
\mathbf{F}\end{array}$ & $\begin{array}{r}88 \\
127\end{array}$ & $\begin{array}{l}19 \\
38\end{array}$ & $\begin{array}{r}84 \\
125\end{array}$ & $\begin{array}{l}19 \\
34\end{array}$ & $\begin{array}{l}23 \\
20\end{array}$ & $\begin{array}{l}8 \\
9\end{array}$ & $\begin{array}{r}2 \\
12\end{array}$ & $\begin{array}{l}1 \\
1\end{array}$ & $\begin{array}{l}244 \\
366\end{array}$ & $\begin{array}{l}19 \cdot 3 \\
22 \cdot 4\end{array}$ \\
\hline
\end{tabular}

Difference between proportions of non-secretors in:

Men and women $x^{2}=0.672, n=1,0.3<P<0.5$

Groups $\mathrm{O}, \mathrm{A}, \mathrm{B}$, and $\mathrm{AB} \chi^{2}=3.446, \mathrm{n}=3,0.3<\mathrm{P}<0.5$

Holborow (1959) for school children in Slough, 15 miles west of the hospital; by McConnell (1961a, and personal communication, 1961b) for healthy persons in Liverpool; and by Newman, Naifeh, Auer, and Buckwalter (1961) for hospital personnel and selected patients in Iowa, U.S.A. The results in all four series are clearly similar. Analysis of the three series which give results separately for men and for women and for each of the ABO blood groups shows that there is no reason to suppose that the proportion of non-secretors varies between the different blood groups, nor that it varies between men and women. It will, however, be seen later that the proportion of non-secretors is usually higher among women than among men in the pathological series and there is reason to believe that there may be a sex difference in the concentrations of the blood group substances in the saliva (Doll and Drane, 1961). Data for the two series have, therefore, been shown separately for each sex throughout the present report, and all comparisons between groups of subjects have been made independently for men and for women.

DUODENAL ULCER The results obtained in patients with a duodenal ulcer are shown in Table IV. Similar data have been published for two other large series and these are included in Table IV for comparison. Since the numbers of patients belonging to the rarer blood groups are small, it has been thought more useful to analyse the results for all these series together, rather than to examine the present results independently. This is justified as it will be shown that the results of the three series are not significantly heterogeneous.

TABLE IV

NUMBER OF SECRETORS AND NON-SECRETORS AMONG DUODENAL ULCER PATIENTS BY SEX AND BLOOD GROUP IN COLLECTED SERIES

\begin{tabular}{|c|c|c|c|c|c|c|c|c|c|c|c|}
\hline \multirow[t]{3}{*}{ Series } & \multirow[t]{3}{*}{$\operatorname{Sex}$} & \multicolumn{8}{|c|}{ Number of Persons in Blood Group } & \multirow{3}{*}{$\begin{array}{l}\text { Total } \\
\text { Number } \\
\text { of } \\
\text { Persons }\end{array}$} & \multirow{3}{*}{$\begin{array}{l}\text { Percentage } \\
\text { of } \\
\text { Non- } \\
\text { secretors }\end{array}$} \\
\hline & & \multicolumn{2}{|l|}{$O$} & \multicolumn{2}{|l|}{$A$} & \multicolumn{2}{|l|}{$B$} & \multicolumn{2}{|l|}{$A B$} & & \\
\hline & & Secretors & $\begin{array}{l}\text { Non- } \\
\text { secretors }\end{array}$ & Secretors & $\begin{array}{l}\text { Non- } \\
\text { secretors }\end{array}$ & Secretors & $\begin{array}{l}\text { Non- } \\
\text { secretors }\end{array}$ & Secretors & $\begin{array}{l}\text { Non- } \\
\text { secretors }\end{array}$ & & \\
\hline McConnell (1961a, 1961b) & $\begin{array}{l}\mathbf{M} \\
\mathbf{F}\end{array}$ & $\begin{array}{r}303 \\
67\end{array}$ & $\begin{array}{r}162 \\
36\end{array}$ & $\begin{array}{r}184 \\
37\end{array}$ & $\begin{array}{l}84 \\
25\end{array}$ & $\begin{array}{l}36 \\
13\end{array}$ & $\begin{array}{r}24 \\
3\end{array}$ & $\begin{array}{r}17 \\
4\end{array}$ & $\begin{array}{l}5 \\
0\end{array}$ & $\begin{array}{l}815 \\
185\end{array}$ & $\begin{array}{l}33 \cdot 7 \\
34 \cdot 6\end{array}$ \\
\hline Newman et al. (1961) & $\begin{array}{l}\mathbf{M} \\
\mathbf{F}\end{array}$ & $\begin{array}{r}156 \\
28\end{array}$ & $\begin{array}{l}62 \\
11\end{array}$ & $\begin{array}{l}83 \\
19\end{array}$ & $\begin{array}{l}44 \\
17\end{array}$ & $\begin{array}{r}22 \\
7\end{array}$ & $\begin{array}{r}13 \\
2\end{array}$ & $\begin{array}{l}8 \\
3\end{array}$ & $\begin{array}{l}3 \\
1\end{array}$ & $\begin{array}{r}391 \\
88\end{array}$ & $\begin{array}{l}31 \cdot 2 \\
35 \cdot 2\end{array}$ \\
\hline $\begin{array}{l}\text { Present duodenal ulcer } \\
\text { patients }\end{array}$ & $\begin{array}{l}\mathbf{M} \\
\mathbf{F}\end{array}$ & $\begin{array}{r}100 \\
23\end{array}$ & $\begin{array}{l}52 \\
17\end{array}$ & $\begin{array}{l}76 \\
15\end{array}$ & $\begin{array}{l}40 \\
13\end{array}$ & $\begin{array}{l}7 \\
5\end{array}$ & $\begin{array}{l}7 \\
3\end{array}$ & $\begin{array}{l}5 \\
2\end{array}$ & $\begin{array}{l}4 \\
0\end{array}$ & $\begin{array}{r}291 \\
78\end{array}$ & $\begin{array}{l}35 \cdot 4 \\
42 \cdot 3\end{array}$ \\
\hline
\end{tabular}

Mean relative incidence among non-secretors compared with secretors, total data,

$\chi^{2}$ for the difference from unity $\quad=62.229, \mathrm{n}=1, \quad \mathrm{P}<0.001$

$x^{2}$ for homogeneity in 18 subzroups $\quad=15.046, n=17,0.3<P<0.5$

$x^{2}$ for homogeneity among men and women $\quad=0.063, \mathrm{n}=1,0.8<\mathrm{P}<0.9$

$x^{2}$ for homogeneity among blood groups $\mathrm{O}, \mathrm{A}$, and $\mathrm{B}$ plus $\mathrm{AB}=3.938, \mathrm{n}=2,0.1<\mathrm{P}<0.2$

$x^{2}$ for homogeneity among the three series

$=3.519, \mathrm{n}=2,0.1<\mathbf{P}<0.2$ 
Comparison of the data shown in Tables III and IV shows that in each series the proportion of nonsecretors is higher among patients with a duodenal ulcer than among the corresponding control subjects. The importance of the difference may be assessed by calculating the relative incidence of duodenal ulcer among non-secretors and secretors. This can be done with the present data, on the assumption that the control subjects are representative in respect of $\mathrm{ABO}$ blood group distribution and secretor status of the populations from which the corresponding duodenal ulcer patients were drawn. With Woolf's method (Woolf, 1955; Roberts, 1957) it is possible to calculate a 'mean relative incidence' for several series, taking account of the varying proportions of duodenal ulcer patients and controls in the different series and the possibility that the proportion of nonsecretors may be different in different subgroups of the control population.

Since the numbers of women patients in blood groups $\mathrm{B}$ and $\mathrm{AB}$ are small, the data for these two blood groups have been combined. The relative incidence of duodenal ulcer among non-secretors and secretors has, therefore, been calculated separately for the 18 subgroups given by the three series, three blood groups $(\mathrm{O}, \mathrm{A}$, and $\mathrm{B}$ plus $\mathrm{AB})$ and two sexes. The mean relative incidence of duodenal ulcer among non-secretors compared with that among secretors is calculated to be 1.80 to 1 ; that is, the incidence of duodenal ulcer is calculated to be $80 \%$ higher among non-secretors than among secretors. The excess is statistically highly significant $(P<0.001)$ and, because of the large number of patients, it can be regarded as accurate within fairly narrow limits. Woolf's method gives fiducial limits for the mean relative incidence of 1.55 to 1 and 2.03 to 1 ; that is, there is a $95 \%$ chance that the true value for the mean relative incidence lies within these limits.

Further analysis shows that the results obtained in the 18 subgroups are consistent with one another and a direct comparison shows no difference between the results ${ }^{1}$ obtained for men and women, blood groups $\mathrm{O}, \mathrm{A}$, and $\mathrm{B}$ plus $\mathrm{AB}$, and the three separate series.

GASTRIC ULCER The results obtained in patients with a gastric ulcer are shown in Table V. As previously, the results of other studies are included for comparison. The data reported by McConnell (1961b) include cases reported previously by Clarke et al. (1959) and by McConnell (1961a); but they exclude cases in which both gastric and duodenal ulcers were present and all cases which were selected as a result of knowledge of their blood groups.

Comparison of the data in Tables III and V shows that in each series the proportions of non-secretors are higher among patients with a gastric ulcer than among the corresponding control subjects. From all the data the mean relative incidence of gastric ulcer among non-secretors compared with that among secretors is calculated to be 1.42 to 1 ; that is, the incidence of gastric ulcer is $42 \%$ higher among nonsecretors than among secretors. The excess is statistically highly significant $(P<0.001)$ and there is a $95 \%$ chance that the true value of the relative incidence lies between the limits of 1.16 and 1.74 to 1 . As in the case of duodenal ulcer, the data can be regarded as homogeneous and there is no need to postulate any difference between the relative incidence for men and for women, the three principal

${ }^{1}$ The method of analysis is described in the appendix.

\begin{tabular}{|c|c|c|c|c|c|c|c|c|c|c|c|}
\hline \multirow[t]{3}{*}{ Series } & \multirow[t]{3}{*}{$\operatorname{Sex}$} & \multicolumn{8}{|c|}{ Number of Persons in Blood Group } & \multirow{3}{*}{$\begin{array}{l}\text { Total } \\
\text { Number } \\
\text { of } \\
\text { Patients }\end{array}$} & \multirow{3}{*}{$\begin{array}{l}\text { Percentage } \\
\text { of } \\
\text { Non- } \\
\text { secretors }\end{array}$} \\
\hline & & \multicolumn{2}{|l|}{$O$} & \multicolumn{2}{|l|}{$A$} & \multicolumn{2}{|l|}{$B$} & \multicolumn{2}{|l|}{$A B$} & & \\
\hline & & Secretors & $\begin{array}{l}\text { Non- } \\
\text { secretors }\end{array}$ & Secretors & $\begin{array}{l}\text { Non- } \\
\text { secretors }\end{array}$ & Secretors & $\begin{array}{l}\text { Non- } \\
\text { secretors }\end{array}$ & Secretors & $\begin{array}{l}\text { Non- } \\
\text { secretors }\end{array}$ & & \\
\hline McConnell (1961b) & $\begin{array}{l}\mathbf{M} \\
\mathbf{F}\end{array}$ & $\begin{array}{l}50 \\
32\end{array}$ & $\begin{array}{l}20 \\
16\end{array}$ & $\begin{array}{l}40 \\
19\end{array}$ & $\begin{array}{l}15 \\
11\end{array}$ & $\begin{array}{r}4 \\
16\end{array}$ & $\begin{array}{l}4 \\
4\end{array}$ & $\begin{array}{l}0 \\
1\end{array}$ & $\begin{array}{l}\mathbf{0} \\
\mathbf{0}\end{array}$ & $\begin{array}{r}133 \\
99\end{array}$ & $\begin{array}{l}29 \cdot 3 \\
31 \cdot 3\end{array}$ \\
\hline Newman et al. (1961) & $\begin{array}{l}\mathbf{M} \\
\mathbf{F}\end{array}$ & $\begin{array}{l}57 \\
18\end{array}$ & $\begin{array}{r}23 \\
6\end{array}$ & $\begin{array}{r}35 \\
6\end{array}$ & $\begin{array}{r}10 \\
3\end{array}$ & $\begin{array}{r}13 \\
3\end{array}$ & $\begin{array}{l}2 \\
1\end{array}$ & $\begin{array}{l}4 \\
1\end{array}$ & $\begin{array}{l}2 \\
0\end{array}$ & $\begin{array}{r}146 \\
38\end{array}$ & $\begin{array}{l}25 \cdot 3 \\
26 \cdot 3\end{array}$ \\
\hline Present gastric ulcer patients & $\begin{array}{l}\mathbf{M} \\
\mathbf{F}\end{array}$ & $\begin{array}{l}31 \\
42\end{array}$ & $\begin{array}{l}13 \\
18\end{array}$ & $\begin{array}{l}32 \\
22\end{array}$ & $\begin{array}{l}13 \\
14\end{array}$ & $\begin{array}{l}6 \\
4\end{array}$ & $\begin{array}{l}2 \\
1\end{array}$ & 1 & $\begin{array}{l}1 \\
1\end{array}$ & $\begin{array}{r}99 \\
103\end{array}$ & $\begin{array}{l}29 \cdot 3 \\
33 \cdot 0\end{array}$ \\
\hline
\end{tabular}

Mean relative incidence among non-secretors compared with secretors, total data,

$x^{2}$ for the difference from unity $=11.636, \mathrm{n}=1, \mathrm{P}<0.001$

$x^{2}$ for homogeneity in 18 subgroups $\quad=8.881, \mathrm{n}=17,0.90<\mathrm{P}<0.95$

$x^{2}$ for homogeneity among men and women $\quad=2 \cdot 527, \mathrm{n}=1,0.1<\mathrm{P}<0.2$

$x^{2}$ for homogeneity among blood groups $\mathbf{O}, \mathbf{A}$, and $B$ plus $\mathbf{A B}=1.982, \mathrm{n}=2,0.1<\mathbf{P}<0.2$

$\chi^{2}$ for homogeneity among the three series

$=1.570, \mathrm{n}=2,0.2<\mathrm{P}<0.3$ 
blood groups $\mathrm{O}, \mathrm{A}$, and $\mathrm{B}$ plus $\mathrm{AB}$, or the three separate series. It may be noted, however, that if the three series are considered independently only one provides clear evidence of a significant excess $(P<0.01)$; in another, the excess is of borderline significance $(P=0.05)$ and in the third it is not significant $(P=0.2<P<0.3)$.

The increase in the incidence of gastric ulcer among non-secretors $(\mathbf{4 2} \%)$ is less than that recorded for duodenal ulcers $(80 \%)$. The difference is substantial and a direct comparison of the data in Tables IV and V shows that the proportions of nonsecretors among patients with the two types of ulcers are significantly different $\left(\chi^{2}=5 \cdot 148, \mathrm{n}=1\right.$, $P=0.03)$.

STOMAL ULCER The results obtained in 83 patients with one or other form of stomal ulcer are shown in Table VI. The only other published data for stomal ulcers were obtained in part by a different technique (Wallace, Brown, Cook, and Melrose, 1958); the two series are not fully comparable and the contents of Table VI are, therefore, limited to the data obtained in the present series. Comparison of the figures in Tables III, IV, and VI shows that in each sex the proportion of non-secretors is substantially higher among stomal ulcer patients than among either the control subjects or patients with a duodenal ulcer.

The numbers of stomal ulcer patients in some of the groups are small and it is not practicable to analyse the results separately for blood groups A, $\mathrm{B}$, and $\mathrm{AB}$. The data for persons belonging to these blood groups have, therefore, been combined and the mean relative incidence of stomal ulcer has been calculated from the data for men belonging to blood group $\mathrm{O}$, men belonging to other groups, women belonging to blood group $\mathrm{O}$, and women belonging to other groups. From comparison with the control subjects (Table III), it is calculated that the incidence of stomal ulcer is 4.22 times greater among nonsecretors than among secretors. This excess is highly significant. The increase in the incidence of stomal ulcers among non-secretors $(322 \%)$ is substantially greater than that recorded for duodenal ulcers $(80 \%)$. Since, however, all the stomal ulcer patients were examined at the Central Middlesex Hospital the more correct comparison is with the duodenal ulcers in the present series. In this subgroup the excess incidence among non-secretors was somewhat larger $(145 \%)^{2}$ and the difference between the stomal and the duodenal ulcer patients is only just statistically significant $(P=0.04)$.

From examination of Table VI it appears that the proportion of non-secretors is higher among stomal ulcer patients belonging to blood group $\mathrm{A}$ than among patients belonging to group $\mathbf{O}$ and that it is higher still among patients belonging to groups $B$ and $\mathrm{AB}$. The numbers of cases are, however, small and a test for homogeneity of the data shows that the variation in the estimates of the relative incidence among non-secretors could easily be due to chance.

CARCINOMA OF STOMACH AND DIABETES MELLITUS Data for 452 cases of carcinoma of the stomach and 420 cases of diabetes mellitus are shown in Table VII. If these are compared with the data for the

\begin{abstract}
${ }^{2}$ The relative incidence of duodenal ulcer among non-secretors, calculated from the results obtained at the Central Middlesex Hospital, was somewhat greater than that obtained from the combined results of all three centres (2.45 to 1 against 1.80 to 1$)$. It has been shown that this difference may well be due to chance (p. 355) and it would have been reasonable to compare the stomal ulcer data with the combined duodenal ulcer data. If this had been done, the difference between the stomal and the duodenal ulcer patients would have been much more marked. There must, however, be some doubt about the complete comparability of the data obtained at the different centres and it seemed safer in this instance to limit the comparison to data obtained at a single centre.
\end{abstract}

TABLE VI

NUMBER OF SECRETORS AND NON-SECRETORS AMONG PATIENTS WITH A STOMAL ULCER BY SEX AND BLOOD GROUP

\begin{tabular}{|c|c|c|c|c|c|c|c|c|c|c|}
\hline \multirow[t]{3}{*}{ Sex } & \multicolumn{8}{|c|}{ Number of Persons in Blood Group } & \multirow{3}{*}{$\begin{array}{l}\text { Total } \\
\text { Number } \\
\text { of } \\
\text { Persons }\end{array}$} & \multirow{3}{*}{$\begin{array}{l}\text { Percentage } \\
\text { of } \\
\text { Non- } \\
\text { secretors }\end{array}$} \\
\hline & \multicolumn{2}{|l|}{$O$} & \multicolumn{2}{|l|}{$\boldsymbol{A}$} & \multicolumn{2}{|l|}{$\boldsymbol{B}$} & \multicolumn{2}{|l|}{$A B$} & & \\
\hline & Secretors & $\begin{array}{l}\text { Non- } \\
\text { secretors }\end{array}$ & Secretors & $\begin{array}{l}\text { Non- } \\
\text { secretors }\end{array}$ & Secretors & $\begin{array}{l}\text { Non- } \\
\text { secretors }\end{array}$ & Secretors & $\begin{array}{l}\text { Non- } \\
\text { secretors }\end{array}$ & & \\
\hline $\begin{array}{l}\mathbf{M} \\
\mathbf{F}\end{array}$ & $\begin{array}{r}26 \\
3\end{array}$ & $\begin{array}{r}13 \\
3\end{array}$ & $\begin{array}{r}11 \\
1\end{array}$ & $\begin{array}{r}18 \\
2\end{array}$ & $\begin{array}{l}\mathbf{0} \\
\mathbf{0}\end{array}$ & $\begin{array}{l}3 \\
2\end{array}$ & $\begin{array}{l}1 \\
0\end{array}$ & $\begin{array}{l}0 \\
0\end{array}$ & $\begin{array}{l}72 \\
11\end{array}$ & $\begin{array}{l}47 \cdot 2 \\
63 \cdot 6\end{array}$ \\
\hline
\end{tabular}

Mean relative incidence among non-secretors compared with secretors:-

1 Comparison between stomal ulcer patients and controls:

$\chi^{2}$ for difference from unity $=27.922, \mathrm{n}=1, \mathrm{P}<0.001$.

Fiducial limits of mean relative incidence, $2 \cdot 47: 1$ and $7 \cdot 20: 1$

$\chi^{2}$ for homogeneity $=4.550, \mathrm{n}=3,0.2<\mathrm{P}<0.3$

2 Comparison between stomal ulcer and duodenal ulcer patients:

$\chi^{2}$ for difference from unity $=4 \cdot 446, \mathrm{n}=1, \mathrm{P}=0.04$

Fiducial limits of mean relative incidence, $1 \cdot 04: 1$ and $2 \cdot 85: 1$

$x^{2}$ for hcmogeneity $=5.365, \mathrm{n}=3,0.1<\mathrm{P}<0.2$ 
TABLE VII

NUMBER OF SECRETORS AND NON-SECRETORS AMONG PATIENTS WITH GASTRIC CANCER OR DIABETES BY SEX AND BLOOD GROUP IN COLLECTED SERIES

\begin{tabular}{|c|c|c|c|c|c|c|c|c|c|c|c|}
\hline \multirow[t]{3}{*}{ Series } & \multirow[t]{3}{*}{$\operatorname{Sex}$} & \multicolumn{8}{|c|}{ Number of Persons in Blood Group } & \multirow{3}{*}{$\begin{array}{l}\text { Total } \\
\text { Number } \\
\text { of } \\
\text { Persons }\end{array}$} & \multirow{3}{*}{$\begin{array}{l}\text { Percent } \\
\text { of } \\
\text { Non- } \\
\text { secretor }\end{array}$} \\
\hline & & \multicolumn{2}{|l|}{$\boldsymbol{O}$} & \multicolumn{2}{|l|}{$A$} & \multicolumn{2}{|l|}{$\boldsymbol{B}$} & \multicolumn{2}{|l|}{$A B$} & & \\
\hline & & Secretors & $\begin{array}{l}\text { Non- } \\
\text { secretors }\end{array}$ & Secretors & $\begin{array}{l}\text { Non- } \\
\text { secretors }\end{array}$ & Secretors & $\begin{array}{l}\text { Non- } \\
\text { secretors }\end{array}$ & Secretors & $\begin{array}{l}\text { Non- } \\
\text { secretors }\end{array}$ & & \\
\hline \multirow[t]{2}{*}{$\begin{array}{l}\text { Carcinoma of stomach } \\
\text { McConnell (1961a, 1961b) }\end{array}$} & $\mathbf{M}$ & 51 & 21 & 44 & 16 & 4 & 3 & 1 & 0 & 140 & $28 \cdot 6$ \\
\hline & $\mathbf{F}$ & 30 & 17 & 17 & 9 & 11 & 4 & 1 & 0 & 89 & $33 \cdot 7$ \\
\hline \multirow[t]{2}{*}{ Newman et al. (1961) } & $\mathbf{M}$ & 26 & 9 & 29 & 7 & 5 & 2 & 2 & 1 & 81 & $23 \cdot 5$ \\
\hline & $\mathbf{F}$ & 8 & $\mathbf{0}$ & 18 & 7 & 3 & $\mathbf{0}$ & 1 & 0 & 37 & $18 \cdot 9$ \\
\hline \multirow[t]{2}{*}{ Present series } & $\mathbf{M}$ & 22 & 7 & 25 & 6 & 10 & 4 & 2 & $\mathbf{0}$ & 76 & $22 \cdot 1$ \\
\hline & $\mathbf{F}$ & 9 & 6 & 8 & 3 & 2 & 1 & 0 & 0 & 29 & $34 \cdot 5$ \\
\hline \multicolumn{12}{|l|}{ Diabetes } \\
\hline McConnell (1961a, 1961b) & $\begin{array}{l}\mathbf{M} \\
\mathbf{F}\end{array}$ & $\begin{array}{l}43 \\
39\end{array}$ & $\begin{array}{l}12 \\
17\end{array}$ & 84 & 27 & $\begin{array}{r}14 \\
6\end{array}$ & 4 & 2 & 4 & 190 & $\begin{array}{l}24 \cdot 7 \\
28 \cdot 1\end{array}$ \\
\hline \multirow[t]{2}{*}{ Present series } & $\mathbf{M}$ & 11 & 3 & 19 & 2 & 3 & 0 & 2 & 0 & 40 & 12.5 \\
\hline & $\mathbf{F}$ & 20 & 5 & 18 & 6 & 9 & 0 & 3 & 1 & 62 & $19 \cdot 4$ \\
\hline
\end{tabular}

'Data not random for blood group.

TABLE VIII

INCIDENCE OF CARCINOMA OF STOMACH AND DIABETES MELLITUS AMONG NON-SECRETORS RELATIVE TO THAT AMONG SECRETORS' DATA FROM TABLES III AND VII

\begin{tabular}{|c|c|c|c|c|c|c|c|c|}
\hline \multirow[t]{2}{*}{ Disease Group } & \multicolumn{2}{|c|}{ Relative Incidence among Non-secretors } & \multicolumn{3}{|c|}{ Difference of Mean Value from Unity } & \multicolumn{3}{|c|}{ Homogeneity of Data } \\
\hline & Mean Value & $\begin{array}{l}95 \% \text { Confidence } \\
\text { Limits }\end{array}$ & $x^{2}$ & $n$ & $\boldsymbol{P}$ & $x^{2}$ & $n$ & $P$ \\
\hline $\begin{array}{l}\text { Carcinoma of stomach } \\
\text { Diabetes mellitus }\end{array}$ & $\begin{array}{l}1 \cdot 27: 1 \\
1.05: 1\end{array}$ & $\begin{array}{l}1 \cdot 01: 1 \text { and } 1 \cdot 60: 1 \\
0.81: 1 \text { and } 1 \cdot 37: 1\end{array}$ & $\begin{array}{l}3.956 \\
0.147\end{array}$ & $\begin{array}{l}1 \\
1\end{array}$ & $\begin{array}{l}0.05 \\
0.7<P<0.8\end{array}$ & $\begin{array}{l}7.984 \\
7.616\end{array}$ & $\begin{array}{r}15^{1} \\
9^{1}\end{array}$ & $\begin{array}{l}0.90<P<0.95 \\
0.5<P<0.7\end{array}$ \\
\hline
\end{tabular}

${ }^{1}$ Because of the small numbers in some of the groups it was necessary to combine into one group all the data for carcinoma of the stomach in women reported by Newman et al. (1961) and to combine the data in the present series for patients with diabetes in blood groups A, B, and AB.

control series given in Table III, it appears that the incidence of both conditions is also somewhat higher among non-secretors than among secretors. For carcinoma of the stomach the excess is about $27 \%$ and this difference is on the border of statistical significance $(P=0.05)$. For diabetes the excess is only $5 \%$ and the true incidence may well be independent of secretor status. The results of the statistical analysis of these data are summarized in Table VIII.

\section{DISCUSSION}

The large amount of information now available shows that stomal, duodenal, and gastric ulcers are all commoner in persons belonging to blood group $O$ than in persons belonging to the other three blood groups. The excess incidence is greatest for stomal ulcer $(80 \%)$, next greatest for duodenal ulcer $(38 \%)$, and least for gastric ulcer (19\%) (Roberts, 1957; Doll, Swynnerton, and Newell, 1960). More recently information has been obtained about the proportions of patients who secrete the blood group substances into their gastrointestinal tracts. The results, analysed in the present paper, show that the incidence of all three types of peptic ulcer is greater among non-secretors than among secretors and that the order of the relationship with non-secretion is the same as that with blood group $O$. The excess incidence is greatest for stomal ulcer $(322 \%)$, next greatest for duodenal ulcer $(80 \%)$, and least for gastric ulcer $(42 \%)$.

The estimates of the incidence of duodenal ulcer and of gastric ulcer among non-secretors are based on large numbers of patients examined at three separate centres and can be regarded as reliable within fairly narrow limits. The figure for stomal ulcer is, however, open to doubt; the numbers are small and the results of the only other published series suggest that the true incidence may be considerably lower. Wallace et al. (1958) reported one non-secretor among four patients with a stomal ulcer belonging to groups $\mathrm{A}, \mathrm{B}$, or $\mathrm{AB}(25 \%)$, and 20 non-secretors among 48 patients with a stomal ulcer belonging to group $\mathrm{O}(42 \%)$. The corresponding proportions of non-secretors among duodenal ulcer patients were $37 \%$ and $40 \%$ and among control subjects $24 \%$ and $29 \%$. In $A, B$, and $A B$ subjects the presence of the blood group substances in the saliva was tested for directly by using group specific antibodies and the results should be comparable 
with those in the present series. In the $O$ subjects, however, non-secretion was determined indirectly by seeing whether the blood cells reacted with anti$\mathrm{Le}^{\mathrm{a}}$ serum. Hence the proportion of non-secretors may have been underestimated, as a result of excluding non-secretors who were Lewis negative.

The explanation of the relationship between group $\mathbf{O}$, non-secretion, and peptic ulcer is not evident. The simplest explanation would be that the presence of the mucopolysaccharide blood group substances in the gastrointestinal secretions helped to protect the mucosa from digestion by the gastric juice and that the $A$ and $B$ substances were more efficient in this respect that the substances secreted by persons belonging to blood group $O$ (Aird, Bentall, Mehigan, and Roberts, 1954). If this were so the blood group effect should be found only among secretors, whereas an equally strong effect has been found among non-secretors (Clarke et al., 1959). This observation is confirmed by the present data. From the figures given in Tables III and IV it can be shown that the mean relative incidence of duodenal ulcer among persons with blood group $\mathbf{O}$ compared with that among persons with blood groups $\mathrm{A}, \mathrm{B}$, or $\mathrm{AB}$ is $1.48: 1$ for secretors and $1.47: 1$ for non-secretors; in both cases the relative incidence is significantly different from unity ( $P<0.001$ and $P=0.001$ respectively). The two estimates are practically identical and it can be concluded with confidence that the effect associated with the different blood groups does not depend upon the presence of the blood group substances in the gastrointestinal secretions. Moreover, the fact that the relative incidences among group $O$ subjects are so similar in secretors and in non-secretors suggests that the risks associated with the two factors are multiplicative. That the risks are multiplicative and not additive can be shown from the data in Tables III and IV in the following way. In the first case, the number of duodenal ulcer subjects expected among group $\mathrm{O}$ non-secretors would be approximately equal to $D_{A S} \times \frac{C_{O N}}{C_{A S}} \times p_{o} p_{n}$, where $\mathbf{D}_{\mathrm{AS}}=$ the number of group $\mathrm{A}, \mathrm{B}$, or $\mathrm{AB}$ secretors among the DU patients,

$\mathrm{C}_{\mathrm{AS}}=$ the number of group $\mathrm{A}, \mathrm{B}$, or $\mathrm{AB}$ secretors among the control subjects,

$\mathrm{C}_{\mathrm{ON}}=$ the number of group $\mathrm{O}$ non-secretors among the control subjects,

$\mathrm{p}_{\mathrm{o}}=$ the relative incidence of DU among group $O$ secretors compared with that among group $\mathrm{A}, \mathrm{B}$, or $\mathrm{AB}$ secretors, and

$p_{n}=$ the relative incidence of DU among group $A, B$, or $A B$ non-secretors compared with that among group $\mathrm{A}, \mathrm{B}$ or $\mathrm{AB}$ secretors.
If, however, the risks were additive, the number of duodenal ulcer subjects expected would be approximately equal to:

$$
D_{A S} \times \frac{C_{O N}}{C_{A S}} \times\left(p_{0}+p_{n}-1\right)
$$

The numbers expected on each hypothesis were calculated separately for men and for women in each of the three series and the results summed. On the first hypothesis the total number of group 0 non-secretors expected among the DU subjects was 336.1 ; on the second hypothesis the expected number was $286 \cdot 5$. The number actually observed was 340 . Clearly the data are compatible with the risks being multiplicative $(0.8<\mathrm{P}<0.9)$; but it is unlikely that they would have been obtained if the risks had been additive $(P<0.01)$. It seems reasonable, therefore, to conclude that the mechanisms by which blood group $\mathrm{O}$ and non-secretion affect the risk of developing a duodenal ulcer are related to one another, although they do not depend on the presence of the blood group substance in the secretions.

Analysis of the data for gastric ulcer, shown in Table V, gives a similar result. If the special risk among persons belonging to blood group $\mathrm{O}$ held only for secretors, the expected number of group $O$ non-secretors among gastric ulcer patients would be $64 \cdot 2$; if the risks were additive, the expected number would be 79.9; if the risks were multiplicative, the expected number would be 88.7 . In fact, the observed number of group $O$ non-secretors was 96. The results clearly accord best with the last hypothesis.

In contrast to these findings the data for stomal ulcer, shown in Table VI, suggest that for this condition the type of $\mathrm{ABO}$ blood group may be unimportant among non-secretors. The numbers are, however, small and the evidence does not weigh heavily against the large body of evidence obtained for patients with gastric or duodenal ulcers. A different mechanism may be involved in the development of stomal ulcer; but it is not possible to reach a definite conclusion on this point until more data are available.

The data for gastric cancer and for diabetes mellitus suggest that there may be a small increase in the risk of the former condition among nonsecretors but that the latter condition is independent of $\mathrm{ABH}$ secretion. Although there is some doubt about diabetes, it is probable that both conditions are commoner among persons belonging to group $\mathbf{A}$ than among persons belonging to group $\mathbf{O}$ and it might be anticipated that they would also differ from peptic ulcer in being commoner among secretors. This, however, is clearly not so and it 
seems probable that the mechanism by which blood group A predisposes to gastric carcinoma and diabetes mellitus differs from the mechanism by which blood (group O) predisposes to peptic ulcer.

We are most grateful to Dr. C. A. Clarke and Dr. R. B. McConnell for providing us with unpublished data and for allowing us to refer to them, to Dr. J. Lennard-Jones for permitting us to include data obtained by him on the secretor status and $\mathrm{ABO}$ blood group of 70 of the duodenal ulcer patients studied at the Central Middlesex Hospital, and to Dr. P. Armitage for suggesting the method of statistical analysis described in the Appendix.

\section{REFERENCES}

Aird, I., Bentall, H. H., Mehigan, J. A., and Roberts, J. A. F. (1954). The blood groups in relation to peptic ulceration and carcinoma of colon, rectum, breast, and bronchus. Brit. med. J., 2, 315-321.

Boyd, W. C., and Shapleigh, E. (1954). Separation of individuals of any blood group into secretors and non-secretors by use of a plant agglutinin (lectin). Blood, 9, 1195-1198.

Clarke, C. A., Edwards, J. W., Haddock, D. R. W., Howel-Evans, A. W., McConnell, R. B., and Sheppard, P. M. (1956). ABO blood groups and secretor character in duodenal ulcer. Brit. med. J., 2, 725-731.

- Evans, D. A. P., McConnell, R. B., and Sheppard, P. M. (1959). Secretion of blood group antigens and peptic ulcer. Ibid, 1, 603-607.

Discombe, G., and Meyer, H. (1952). The capillary-tube method of rhesus testing. Amer. J. clin. Path., 22, 543-548.

Doll, R., and Drane, H. (1961). To be published.

$\longrightarrow$, Swynnerton, B. F., and Newell, A. C. (1960). Observations on blood group distribution in peptic ulcer and gastric cancer. Gut, 1, 31-35.

Glynn, A. A., Glynn, L. E., and Holborow, E. J. (1959). Secretion of blood-group substances in rheumatic fever. Brit. med. J., 2, 266-270.

McConnell, R. B. (1961a). The mechanism by which blood groups antigens influence gastrointestinal disorders. Proc. int. Congr. Gastroenterology, Leyden, 1960, pp. 41-45.

- (1961b). Personal communication.

Newman, E., Naifeh, G. S., Auer, J. E., and Buckwalter, J. A. (1961). Secretion of $\mathrm{ABH}$ antigens in peptic ulceration and gastric carcinoma. Brit. med. J., 1, 92-94.

Roberts, J. A. F. (1957). Blood groups and susceptibility to disease. A review. Brit. J. prev. soc. Med., 11, 107-125.

Wallace, J., Brown, D. A. P., Cook, I. A., and Melrose, A. G. (1958). The secretor status in duodenal ulcer. Scot. med. J., 3, 105-109.

Woolf, B. (1955). On estimating the relation between blood group and disease. Ann. hum. Genet., 19, 251-253.

\section{A P P E N D I X}

Let the numbers of non-secretors and of secretors in the disease series be $h$ and $k$ and in the corresponding control series be $H$ and $K$. Then the incidence of the disease among non-secretors relative to that among secretors is hK/HK.

With Woolf's (1955) notation, let

$$
\mathrm{x}=\mathbf{h K} / \mathbf{H k} \text {, }
$$

and $y=\log _{\mathrm{e}} \mathrm{x}$;

then $V(y)$, the variance of $y,=\left(\frac{1}{h}+\frac{1}{k}+\frac{1}{H}+\frac{1}{K}\right)$.

Let $w=1 / V(y)$,

and $Y=$ the logarithm of the mean relative incidence of the disease among non-secretors for all the various groups examined.

Then $\mathbf{Y}=\mathbf{S w y} / \mathbf{S w}$

and $\chi^{2}$, for the difference of the mean relative incidence from unity, $=(\mathrm{S} w \mathrm{w})^{2} / \mathrm{Sw}$ with one degree of freedom and $x^{2}$. for the homogeneity of the groups, $=\mathrm{Swy}^{2}-$ $(\mathrm{Swy})^{2} / \mathrm{Sw}$, with degrees of freedom one less than the number of groups.

The homogeneity of the results for men and for women may be tested separately as follows:

Let $y_{m}$ be the value of $y$ obtained for men in any one blood group at one centre, and $y_{f}$ be the corresponding value for women.

Let $z=y_{t}-y_{m}$

Then $V(z)$, the variance of $z,=V\left(y_{p}\right)+V\left(y_{m}\right)$

Let $\mathrm{w}_{\mathbf{z}}=1 / \mathrm{V}(\mathrm{z})$

Then $\bar{z}$, the weighted mean of $z,=S w_{z} z / S_{z}$ and $\chi^{2}$, for the difference of $\bar{z}$ from zero, $=\left(\mathbf{S w}_{\mathrm{z}} \mathrm{z}\right)^{2} / \mathbf{S w}_{\mathbf{z}}$ with one degree of freedom.

The homogeneity of the results for the three centres may be tested as follows:

Let $y_{1}, y_{2}$, and $y_{3}$ be the values of $y$ obtained at each of the three centres for one sex and one blood group.

Then $\bar{y}_{1}=S y_{1} / 6$,

$\mathrm{V}\left(\mathrm{y}_{1}\right)=\mathrm{S}\left[\mathrm{V}\left(\mathrm{y}_{1}\right)\right] / 36$, and $\mathrm{W}_{1}=1 / \mathrm{V}\left(\overline{\mathrm{y}}_{1}\right)$.

Then $x^{2}$, for homogeneity, $=S W_{1} \bar{y}_{1}^{2}-\frac{S\left(W_{1} \bar{y}_{1}\right)^{2}}{S W_{1}}$ with 2 degrees of freedom.

The homogeneity of the results for the three principal blood groups may be tested in the same way as the results for the three centres. 